\title{
Bomb radiocarbon dating of three important reef-fish species using Indo-Pacific $\Delta^{14} \mathrm{C}$ chronologies
}

\author{
Allen H. Andrews ${ }^{\mathrm{A}, \mathrm{F}}$, John M. Kalish ${ }^{\mathrm{B}, \mathrm{C}}$, Stephen J. Newman ${ }^{\mathrm{D}}$ \\ and Justine M. Johnston ${ }^{\mathrm{B}, \mathrm{E}}$ \\ ${ }^{A}$ NOAA Fisheries, Pacific Islands Fisheries Science Center, 99-193 Aiea Heights Drive \#417, \\ Aiea, HI 96701, USA. \\ ${ }^{B}$ Division of Evolution, Ecology and Genetics, Research School of Biology, Australian National \\ University, Canberra, ACT 0200, Australia. \\ ${ }^{C}$ Present address: Australian Safeguards and Non-Proliferation Office, Department of Foreign \\ Affairs and Trade, Barton, ACT 0221, Australia. \\ DWestern Australian Fisheries and Marine Research Laboratories, Department of Fisheries, \\ Government of Western Australia, PO Box 20, North Beach, WA 6920, Australia. \\ ${ }^{E}$ Australian Fisheries Management Authority, PO Box 7051, Canberra BC, ACT 2610, Australia. \\ FCorresponding author. Email: allen.andrews@noaa.gov
}

\begin{abstract}
Demersal reef fishes of the Indo-Pacific are under increasing pressure as a fisheries resource, yet many of the important life history characteristics required for suitable management are poorly known. The three fish species, eightbar grouper (Hyporthodus octofasciatus), ruby snapper (Etelis carbunculus) and the spangled emperor (Lethrinus nebulosus), are important components of fisheries and ecosystems throughout the Indo-Pacific. Despite their importance, age and growth information is incomplete. Age has been estimated for E. carbunculus and L. nebulosus, but validated age beyond the first few years is lacking and for $H$. octofasciatus no age estimates exist. Bomb radiocarbon dating can provide age estimates that are independent of growth-zone counting, but only if appropriate reference $\Delta^{14} \mathrm{C}$ chronologies exist. In this study, a series of $\Delta^{14} \mathrm{C}$ records from hermatypic corals was assembled to provide a basis for bomb radiocarbon dating in the western Indo-Pacific region. Results provided (1) valid age estimates for comparison to age estimates from two facilities investigating growth-zones in otolith thin sections; (2) support for age estimation protocols using otolith thin sections; and (3) the information necessary for further refinement of age estimation procedures. Estimates of longevity from bomb radiocarbon dating agree with some prior studies: H. octofasciatus, E. carbunculus and L. nebulosus all being long-lived species with life spans of at least 43,35 and 28 years respectively.
\end{abstract}

Additional keywords: age validation, carbon-14, Epinephelidae, Indian Ocean, Lethrinidae, longevity, Lutjanidae.

Manuscript received 6 April 2011, accepted 15 July 2011, published online 29 September 2011

\section{Introduction}

Demersal reef fishes of the Indo-Pacific are under increasing pressure as a fisheries resource, yet many of the important life history characteristics required for suitable assessment, monitoring and management are poorly known. To achieve sustainable fisheries management, age estimation protocols need to be validated for effective stock assessment modelling that relies on age-structured data (Beamish et al. 2006; Cailliet and Andrews 2008). With age data available, fishery managers can (1) understand and monitor population age structure for long-term changes; (2) determine the timing of important life history events, such as the age at recruitment to the fishery or size and age at maturity; (3) determine vital demographic rates, such as growth and natural mortality; and (4) monitor the longterm effects of fishing mortality. Members of three key reef fish families (Epinephelidae, Lutjanidae and Lethrinidae) are important to commercial and recreational fisheries of the Indo-Pacific. These fishes can possess life history attributes that make them vulnerable to overexploitation, such as slow growth, long life spans, low rates of natural mortality, late age at maturity and variable recruitment (e.g. Newman et al. 2000; Pears et al. 2006; Marriott et al. 2011). In this study, we examined the validity of age and longevity estimates for three species, representing these reef fish families, from important fisheries off Western Australia: the eightbar grouper (Hyporthodus octofasciatus), ruby snapper (Etelis carbunculus) and spangled emperor (Lethrinus nebulosus).

Despite the importance of these fishes, little is known about their age and growth and even where age has been estimated, only the first few years of growth have been validated. The least 
known in terms of age and growth is $H$. octofasciatus and no age estimates have been published to date. An age and growth study on E. carbunculus from Papua New Guinea provided unconfirmed estimates of 4 to 28 years from thin-sectioned otoliths (Fry et al. 2006). Some age and growth studies of E. carbunculus from more easterly Pacific locations cannot be considered comparable with the central Indo-Pacific because of the latest genetic information; there will be a taxonomic reclassification of this species as Etelis marshi for Hawaii and a range of other islands ( $\mathrm{K}$. Andrews, pers. comm.). The exception may be for Vanuatu where fish reach a greater size $(1270 \mathrm{~mm}$ fork length (FL) for Vanuatu cf. 540-700 mm FL for western Central Pacific (Uchida et al. 1982; Smith and Kostlan 1991)). This region of the Indo-Pacific is likely dominated by E. carbunculus based on otolith morphology and genetic information (Smith 1992; K. Andrews, pers. comm.). From Vanuatu, Smith and Kostlan (1991) analysed 13 fish and estimated an age of $<10$ years for a fish approaching maximum observed length. However, the age estimates were based on an extrapolation of the daily increment data, which can underestimate the age of the largest fish (e.g. Ralston and Miyamoto 1983). L. nebulosus is perhaps the most thoroughly studied of the three species. Loubens (1980) used otolith thin-sections to estimate ages up to 27 years, with validation to $\sim 8$ years using marginal increment analysis. More recently, an application of a cut-and-burn technique provided similar results to those by Loubens (1980), with a maximum estimated age of 26 years (Ebisawa and Ozawa 2009). In addition, Marriott et al. (2011) derived a maximum estimated age of 31 years from otolith thin sections with validation of early growth using monthly margin type. All these species lack validated age estimates for the largest fish and longevity is unknown.

Age validation can be difficult to achieve for deepwater or long-lived fishes, and bomb radiocarbon dating has evolved as a unique application aimed at addressing this problem. The approach relies on a conserved record of the rapid increase in radiocarbon that occurred in the oceans of the world as a result of atmospheric testing of thermonuclear devices in the 1950s and '60s (Broecker and Peng 1982). The uptake of bomb-produced radiocarbon by the marine environment, reported as delta carbon-14 $\left(\Delta^{14} \mathrm{C}\right)$ in reference to an established pre-nuclear radiocarbon record (Stuiver and Polach 1977), was virtually synchronous in the mixed layer of mid-latitude oceans and this signal was first recorded from marine carbonates in hermatypic corals (Druffel and Linick 1978). This time-specific signal provides a reference period that can be used to determine age. The application of bomb radiocarbon dating to fishes began with an innovative comparison of $\Delta^{14} \mathrm{C}$ values recorded in otolith carbonate (core material) relative to regional $\Delta^{14} \mathrm{C}$ records from hermatypic corals of the Great Barrier Reef (Kalish 1993). In this and other studies, measured $\Delta^{14} \mathrm{C}$ levels provided an independent determination of age for corroboration of age estimates from growth-zone counting in otoliths (Campana 1997; Kalish et al. 2001). Bomb radiocarbon dating has since been applied successfully to the otoliths of many species of teleost fishes to validate estimated age (e.g. Andrews et al. 2007; Ewing et al. 2007; Neilson and Campana 2008) and an important factor for a successful application is assembling a suitable regional $\Delta^{14} \mathrm{C}$ reference chronology.
The focus of this study was to assemble a regional $\Delta^{14} \mathrm{C}$ reference chronology for the western Indo-Pacific and to use it to ascertain age and longevity for H. octofasciatus, E. carbunculus and L. nebulosus. The study fish were collected from off Western Australia, and it was hypothesised that $\Delta^{14} \mathrm{C}$ records from the Indian Ocean and central Indo-Pacific could be compiled to provide a valid reference to validate age using bomb radiocarbon dating. Once the $\Delta^{14} \mathrm{C}$ chronology was assembled, it was further hypothesised that (1) an independent estimate of age could be determined for the three species from a correlation of measured $\Delta^{14} \mathrm{C}$ in otolith cores with the regional $\Delta^{14} \mathrm{C}$ reference chronology; (2) the validity of age estimates from growth-zone counting in otolith thin sections could be evaluated from bomb radiocarbon dating; and (3) an estimate of longevity could be determined for these species from the $\Delta^{14} \mathrm{C}$ measurements.

\section{Materials and methods}

Sample processing and age estimation

Sagittal otoliths of Hyporthodus octofasciatus, Etelis carbunculus and Lethrinus nebulosus were selected from the otolith archives maintained at the Western Australian Fisheries and Marine Research Laboratories (WAFMRL, Perth, WA). Specimens of $H$. octofasciatus were collected from the Ningaloo Reef area $\left(\sim 22^{\circ} 05^{\prime} \mathrm{S}, 113^{\circ} 42^{\prime} \mathrm{E}\right)$ and Scott Reef $\left(\sim 14^{\circ} 05^{\prime} \mathrm{S}\right.$, $121^{\circ} 44^{\prime} \mathrm{E}$; Table 1) during November $1997(n=10)$. All specimens of E. carbunculus were collected from the Ningaloo Reef area (Table 2) during November $1997(n=10)$. Specimens of $L$. nebulosus were collected from the Houtman Abrolhos Islands area $\left(\sim 28^{\circ} 42^{\prime} \mathrm{S}, 113^{\circ} 49^{\prime} \mathrm{E}\right)$, Exmouth $\left(\sim 21^{\circ} 47^{\prime} \mathrm{S}\right.$, $\left.114^{\circ} 11^{\prime} \mathrm{E}\right)$ and Broome $\left(\sim 18^{\circ} 00^{\prime} \mathrm{S}, 122^{\circ} 07^{\prime} \mathrm{E}\right.$; Table 3$)$ during 1990-91 ( $n=10)$.

For each individual, length (standard length, SL; fork length, FL) was measured where possible and both sagittal otoliths were removed and cleaned. Otoliths were measured and weighed to the nearest $0.1 \mathrm{mg}$. One otolith from each fish was selected at random and embedded in soft epoxy resin. Three transverse sections were cut with a low speed saw and a diamond-wafering blade in the vicinity of the otolith primordium. The sections were $0.25-0.50 \mathrm{~mm}$ thick and were lightly polished on wet carborundum paper (1000 grade) and lapping film (3 and $9 \mu \mathrm{m})$ and mounted on microscope slides. The second and third authors estimated ages by counting opaque zones on the thin sections under magnifications between $7.5 \times$ and $25.2 \times$ with a stereo dissecting microscope using transmitted white light, or under reflected light against a dark background (Newman et al. 1996). Birth years for both readings were estimated by subtracting the growth zone-derived age from the year of collection for each fish. The majority of otoliths selected for bomb radiocarbon dating were from older individuals with a presumed birth date commensurate with the period of rapid increase in $\Delta^{14} \mathrm{C}$ (i.e. between $\sim 1955$ and 1970).

\section{Radiocarbon analysis}

The second otolith was prepared for radiocarbon analysis by extracting otolith core material. Methods used were similar to those described elsewhere (e.g. Kalish et al. 1996; Kalish 2001). Otolith aragonite deposited during a period presumed to be less 
Table 1. Fish, otolith, radiocarbon and estimated age data for Hyporthodus octofasciatus caught by line fishing in November 1997 $\Delta^{14} \mathrm{C}$ birth year and age range were determined from the $\Delta^{14} \mathrm{C}$ reference records (Fig. $2 a$ ). Growth zone age was the estimation made by three readers at two ageing facilities, WAFMRL (WA-1,2) and ANU (ANU-1). Age estimate correlation (*) is a basic indicator of whether growth zone-derived age provided a calculated birth year that fell within the range possible for the $\Delta^{14} \mathrm{C}$ reference records to within a \pm 1 year tolerance (Fig. $2 b$ ). WAFMRL, Western Australian Fisheries and Marine Research Laboratories (Perth, Australia); ANU, Australian National University

\begin{tabular}{|c|c|c|c|c|c|c|c|c|}
\hline \multirow{2}{*}{$\begin{array}{l}\text { Sample } \\
\text { number }\end{array}$} & \multirow{2}{*}{$\begin{array}{l}\text { Length } \\
(\mathrm{mm}) \mathrm{SL}\end{array}$} & \multirow{2}{*}{$\begin{array}{c}\text { Otolith } \\
\text { weight } \\
\text { (g) }\end{array}$} & \multirow{2}{*}{$\begin{array}{l}\Delta^{14} \mathrm{C} \\
(\% o)\end{array}$} & \multirow{2}{*}{$\begin{array}{c}\Delta^{14} \mathrm{C} \\
\text { Birth year }\end{array}$} & \multirow{2}{*}{$\begin{array}{c}\Delta^{14} \mathrm{C} \\
\text { Age (years) }\end{array}$} & \multicolumn{3}{|c|}{ Growth zone age (birth year) } \\
\hline & & & & & & $\begin{array}{l}\text { WA-1 } \\
\text { (years) }\end{array}$ & $\begin{array}{l}\text { WA-2 } \\
\text { (years) }\end{array}$ & $\begin{array}{l}\text { ANU-1 } \\
\text { (years) }\end{array}$ \\
\hline S2365 & 516 & 0.3312 & $87.9 \pm 5.2$ & $1965-70,>1979$ & $<19,28-33^{\mathrm{A}}$ & $9(1988)^{*}$ & $8(1989)^{*}$ & $15(1982)^{*}$ \\
\hline S291 & 661 & 0.7125 & $111.5 \pm 4.4$ & $1967-89$ & $9-31$ & $30(1967)^{*}$ & $18(1979)^{*}$ & $32(1965)^{*}$ \\
\hline S296 & 688 & 0.8743 & $116.2 \pm 4.6$ & $1967-89$ & $9-31$ & $28(1969)^{*}$ & $18(1979)^{*}$ & $36(1961)$ \\
\hline S2346 & 695 & 1.1128 & $137.6 \pm 8.7$ & $1968-82$ & $16-30$ & $24(1973)^{*}$ & $25(1972)^{*}$ & $31(1966)^{*}$ \\
\hline S283 & 949 & 1.2256 & $144.3 \pm 4.9$ & $1970-79$ & $19-28$ & $26(1971)^{*}$ & $26(1971)^{*}$ & $26(1971)^{*}$ \\
\hline S282 & 983 & 1.3791 & $-9.4 \pm 4.8$ & $1960-64,1955$ & $34-38,43^{\mathrm{B}}$ & $34(1963)^{*}$ & $28(1969)$ & $37(1960)^{*}$ \\
\hline $\mathrm{S} 270$ & 1028 & 1.8202 & $-68.9 \pm 5.4$ & $<1955$ & $>43$ & 32 (1965) & $34(1963)$ & 40 (1957) \\
\hline S2386 & 1220 & 2.3716 & $-60.7 \pm 4.7$ & $<1958$ & $>40$ & $36(1961)$ & 37 (1960) & $42(1955)^{*}$ \\
\hline S2389 & 1240 & 3.0405 & $-67.4 \pm 4.6$ & $<1955$ & $>43$ & 37 (1960) & $41(1956)^{*}$ & $46(1951)^{*}$ \\
\hline
\end{tabular}

${ }^{\mathrm{A}}$ Crossed rise and decline periods.

${ }^{\mathrm{B}}$ Remote possibility of encountering minor spike measured for 1955 .

Table 2. Fish, otolith, radiocarbon, and estimated age data for Etelis carbunculus caught by line fishing in November 1997 $\Delta^{14} \mathrm{C}$ birth year and age range were determined from the $\Delta^{14} \mathrm{C}$ reference records (Fig. $3 a$ ). Age estimate correlation $(*)$ is a basic indicator of growth-zone age agreement with the $\Delta^{14} \mathrm{C}$ reference (Fig. $3 b$ )

\begin{tabular}{|c|c|c|c|c|c|c|c|c|}
\hline \multirow{2}{*}{$\begin{array}{l}\text { Sample } \\
\text { number }\end{array}$} & \multirow{2}{*}{$\begin{array}{l}\text { Length } \\
(\mathrm{mm}) \mathrm{SL}\end{array}$} & \multirow{2}{*}{$\begin{array}{c}\text { Otolith } \\
\text { weight } \\
\text { (g) }\end{array}$} & \multirow{2}{*}{$\begin{array}{l}\Delta^{14} \mathrm{C} \\
(\% o)\end{array}$} & \multirow{2}{*}{$\begin{array}{c}\Delta^{14} \mathrm{C} \\
\text { Birth year }\end{array}$} & \multirow{2}{*}{$\begin{array}{c}\Delta^{14} \mathrm{C} \\
\text { Age (years) }\end{array}$} & \multicolumn{3}{|c|}{ Growth zone age (birth year) } \\
\hline & & & & & & $\begin{array}{l}\text { WA-1 } \\
\text { (years) }\end{array}$ & $\begin{array}{l}\text { WA-2 } \\
\text { (years) }\end{array}$ & $\begin{array}{l}\text { ANU-1 } \\
\text { (years) }\end{array}$ \\
\hline S400 & 268 & 0.0340 & $83.2 \pm 4.7$ & $1966-70,>1979$ & $<19,28-33^{\mathrm{A}}$ & $5(1992)^{*}$ & $3(1994) *$ & $8(1989) *$ \\
\hline S567 & 310 & 0.0450 & $79.0 \pm 4.1$ & $1965-68,>1982$ & $<16,30-33^{\mathrm{A}}$ & $9(1988)^{*}$ & $6(1991)^{*}$ & $9(1988)^{*}$ \\
\hline S485 & 512 & 0.1586 & $107.3 \pm 4.4$ & $1966-95$ & $3-32$ & $14(1983)^{*}$ & $17(1980)^{*}$ & $19(1978)^{*}$ \\
\hline S477 & 663 & 0.1650 & $120.5 \pm 4.6$ & $1967-86^{\mathrm{B}}$ & $12-31^{\mathrm{B}}$ & $18(1979) *$ & $17(1980)^{*}$ & $18(1979)^{*}$ \\
\hline S444 & 712 & 0.2402 & $124.2 \pm 4.5$ & $1967-86^{\mathrm{B}}$ & $12-31^{\mathrm{B}}$ & $21(1976)^{*}$ & $20(1977)^{*}$ & $33(1964)$ \\
\hline S449 & 807 & 0.2711 & $120.7 \pm 4.5$ & $1967-86^{\mathrm{B}}$ & $12-31^{\mathrm{B}}$ & $29(1968)^{*}$ & $26(1971)^{*}$ & $25(1972)^{*}$ \\
\hline S388 & 884 & 0.3291 & $84.7 \pm 4.3$ & $1966-70,>1979$ & $<19,28-32^{\mathrm{C}}$ & $24(1973)$ & $30(1967)^{*}$ & $27(1970)^{*}$ \\
\hline S431 & 886 & 0.4502 & $-21.2 \pm 4.1$ & $1963-59,1955$ & $35-39,43^{\mathrm{D}}$ & $33(1964)$ & $34(1963)^{*}$ & $33(1964)$ \\
\hline S447 & 886 & 0.3154 & $106.7 \pm 4.7$ & $1966-95$ & $3-32$ & $28(1969) *$ & $27(1970)^{*}$ & $24(1973)^{*}$ \\
\hline S435 & 932 & 0.3601 & $75.1 \pm 5.0$ & $1965-68,>1982$ & $<16,30-33^{\mathrm{C}}$ & 38 (1959) & $30(1967)^{*}$ & $28(1969)$ \\
\hline
\end{tabular}

${ }^{\mathrm{A}}$ Crossed rise and decline periods.

${ }^{\mathrm{B}}$ Narrower peak interpretation based on similarity in amplitude of $\Delta^{14} \mathrm{C}$ to $\operatorname{Cocos}(1968-82=16-30$ years).

${ }^{\mathrm{C}}$ Younger classification can be ruled out based on smaller fish with similar $\Delta^{14} \mathrm{C}$ levels.

${ }^{\mathrm{D}}$ Remote possibility of encountering minor spike measured for 1955.

than the first 6 months of life was isolated from the sagitta of each fish. The earliest formed portion of individual otoliths was isolated with a fine-tipped, high-speed drill. This was achieved by 'sculpting' from the larger otolith to the size and weight of an otolith that was known to represent an otolith of $\sim 6$ months of age. Microscopic observations were made to guide the coring to ensure the centre was extracted. The final product was a single piece of otolith aragonite that encompassed the core region of the otolith. Extracted sample weights ranged from $\sim 8.6$ to $15.5 \mathrm{mg}$ (Tables 1, 2 and 3).

Radiocarbon analyses were similar to previously reported procedures. Otolith carbonate from the extracted cores was converted to $\mathrm{CO}_{2}$ by reaction in vacuo with $100 \%$ phosphoric acid. An aliquot of the $\mathrm{CO}_{2}$ was used to determine $\delta{ }^{13} \mathrm{C}$ for each sample to account for isotopic fractionation and the remaining
$\mathrm{CO}_{2}$ was graphitised for analysis of radiocarbon using accelerator mass spectrometry (AMS). Radiocarbon values are reported as $\Delta^{14} \mathrm{C}$, which is the age- and fractionation-corrected per mil deviation from the activity of 19th century wood (Stuiver and Polach 1977). Age corrections were based on the mean estimate of age determined from reading of otolith sections. Errors were reported as 1 s.d. for both radiocarbon data and age estimates based on the reading of otolith sections. The error associated with $\Delta^{14} \mathrm{C}$ determinations included both counting and laboratory random errors.

\section{Regional $\Delta^{14} \mathrm{C}$ reference chronology}

Regional reference records from the Indian Ocean and central Indo-Pacific regions were gathered to provide an age calibration 
Table 3. Fish, otolith, radiocarbon, and estimated age data for Lethrinus nebulosus caught by line fishing in 1990-91 $\Delta^{14} \mathrm{C}$ birth year and age range were determined from the $\Delta^{14} \mathrm{C}$ reference records (Fig. $4 a$ ). Age estimate correlation $(*)$ is a basic indicator of growth-zone age agreement with the $\Delta^{14} \mathrm{C}$ reference (Fig. $4 b$ )

\begin{tabular}{|c|c|c|c|c|c|c|c|c|}
\hline \multirow{2}{*}{$\begin{array}{l}\text { Sample } \\
\text { number }\end{array}$} & \multirow{2}{*}{$\begin{array}{l}\text { Length } \\
(\mathrm{mm}) \mathrm{FL}\end{array}$} & \multirow{2}{*}{$\begin{array}{l}\text { Otolith } \\
\text { weight } \\
\text { (g) }\end{array}$} & \multirow{2}{*}{$\begin{array}{l}\Delta^{14} \mathrm{C} \\
(\%)\end{array}$} & \multirow{2}{*}{$\begin{array}{c}\Delta^{14} \mathrm{C} \\
\text { Birth year }\end{array}$} & \multirow{2}{*}{$\begin{array}{c}\Delta^{14} \mathrm{C} \\
\text { Age (years) }\end{array}$} & \multicolumn{3}{|c|}{ Growth zone age (birth year) } \\
\hline & & & & & & $\begin{array}{l}\text { WA-1 } \\
\text { (years) }\end{array}$ & $\begin{array}{l}\text { WA-2 } \\
\text { (years) }\end{array}$ & $\begin{array}{l}\text { ANU-1 } \\
\text { (years) }\end{array}$ \\
\hline N16 & 297 & 0.1197 & $103.5 \pm 9.5$ & $>1967$ & $0-24,2^{\mathrm{A}}$ & $2(1988)^{*}$ & - & - \\
\hline N14 & 500 & 0.2517 & $156.1 \pm 10.0$ & $1968-82$ & $9-23$ & $5(1985)$ & - & - \\
\hline N4 & 503 & 0.6240 & $147.3 \pm 7.1$ & $1968-82$ & $9-23$ & $26(1965)$ & - & - \\
\hline N9 & 505 & 0.4065 & $175.6 \pm 15.4$ & $1970-77^{\mathrm{C}}$ & $14-21^{\mathrm{B}}$ & $15(1975)^{*}$ & - & - \\
\hline N10 & 517 & 0.4373 & $178.9 \pm 16.3$ & $1970-77^{\mathrm{C}}$ & $14-21^{\mathrm{B}}$ & $15(1975)^{*}$ & - & - \\
\hline N13 & 518 & 0.4303 & $117 \pm 9.3$ & $1967-88$ & $3-24$ & $10(1980)^{*}$ & - & - \\
\hline N1 & 520 & 0.6558 & $9.4 \pm 8.4$ & $1962-65$ & $27-30$ & $26(1965)^{*}$ & - & - \\
\hline N3 & 522 & 0.5857 & $-10.3 \pm 8.2$ & $1960-64,1955$ & $27-31,36^{\mathrm{D}}$ & $26(1965)^{*}$ & - & - \\
\hline $\mathrm{N} 2$ & 553 & 0.6015 & $-19.8 \pm 8.1$ & $1959-63,1955$ & $28-32,37^{\mathrm{D}}$ & $27(1964)^{*}$ & - & - \\
\hline N5 & 585 & 0.7004 & $4.8 \pm 8.2$ & $1962-64$ & $26-28$ & $27(1963)^{*}$ & - & - \\
\hline
\end{tabular}

${ }^{\mathrm{A}}$ This otolith can function as $\Delta^{14} \mathrm{C}$ reference material because juvenile age was less questionable.

${ }^{\mathrm{B}}$ Peak values and reference curve shape not known; rough estimate from an approximation.

${ }^{\mathrm{C}}$ Roughly estimated from range of $\Delta^{14} \mathrm{C}$ associated with the Mauritius coral $\Delta^{14} \mathrm{C}$ record.

${ }^{\mathrm{D}}$ Remote possibility of encountering minor spike measured for 1955.

source for the measured $\Delta{ }^{14} \mathrm{C}$ values from otolith cores of H. octofasciatus, E. carbunculus and L. nebulosus. The most reliable recorders of changes in marine $\Delta^{14} \mathrm{C}$ were from hermatypic corals. Records of the rise in $\Delta^{14} \mathrm{C}$ were selected based on oceanographic considerations such as historical $\Delta^{14} \mathrm{C}$ records from seawater and surface circulation modelling and the proximity of fish collection sites to the reference data. In most cases, a combination of records was used to cover a range of possible $\Delta^{14} \mathrm{C}$ levels for a given year-of-formation because the actual environmental levels at the locations of fish collections were unknown.

\section{Bomb radiocarbon dating}

Age was estimated by graphical projection of the measured $\Delta^{14} \mathrm{C}$ values back in time from the measurement date to the regional $\Delta^{14} \mathrm{C}$ reference series. First, a birth year was estimated based on the correlation between the measured $\Delta^{14} \mathrm{C}$ value and the regional $\Delta^{14} \mathrm{C}$ reference records, which were initially attributed to a general region of the curve (pre-bomb, bomb rise, peak or post-bomb decline). For pre-bomb levels, minimum birth year and age were estimated based on the last year the level was measured, plus a nominal uncertainty of $\sim 1-2$ years based on the minor variations in the rise of $\Delta^{14} \mathrm{C}$. For levels measured near the regional peak and upper part of the $\Delta^{14} \mathrm{C}$ rise, there were complications with birth year classification because of the similar levels measured through time in the post-bomb period. Samples that could be placed on the bomb rise period were diagnostic and were assigned an age with a relatively narrow uncertainty.

Age estimates from growth zone counting by three age readers were evaluated relative to the possible birth years determined from bomb radiocarbon dating. The age estimates from each reader were classified as either in agreement with the $\Delta^{14} \mathrm{C}$ record or not in agreement. Age estimate correlation was a basic indicator of whether growth zone-derived age provided a calculated birth year that fell within the range possible from the $\Delta^{14} \mathrm{C}$ reference records and within a $\pm 1-2$ year tolerance based graphically on the variability of the $\Delta^{14} \mathrm{C}$ rise and decline. These growth-zone age data were plotted with the regional $\Delta^{14} \mathrm{C}$ reference records based on calculated birth years from each age reader. Age estimates from bomb radiocarbon dating that were considered diagnostic from a narrow fit to reference $\Delta^{14} \mathrm{C}$ records were summarised separately and discussed relative to previous age and growth studies for each species. Other information, such as otolith weight and fish length relationships, was used to provide an insight into estimates of longevity.

\section{Results}

\section{Regional $\Delta^{14} \mathrm{C}$ reference chronology}

The $\Delta^{14} \mathrm{C}$ records of hermatypic corals considered useful in this study ranged across the Indian Ocean from as far west as Kenya and Mauritius, to the Cocos (Keeling) Islands and Sumatra in the north central Indian Ocean, and into the Indo-Pacific region off Bali and Borneo (Toggweiler and Dixon 1991; Grumet et al. 2002, 2004; Hua et al. 2004, 2005; Fallon and Guilderson 2008; Guilderson et al. 2009; Fig. 1). Because there were no hermatypic coral $\Delta^{14} \mathrm{C}$ records from Western Australia, oceanic seawater $\Delta^{14} \mathrm{C}$ records and hyrdrography were used to establish potential similarities from more distant sources of $\Delta^{14} \mathrm{C}$ information. Note that pre-bomb levels were relatively consistent over time and across regions, but that the rise in $\Delta^{14} \mathrm{C}$ was phase lagged by a few years for the more Indo-Pacific records (Grumet et al. 2004). In general, the timing of the rise in $\Delta^{14} \mathrm{C}$ was similar for the chosen records and close to 1955 , but the phase of the continued rise in $\Delta^{14} \mathrm{C}$ was offset later in time by $2-3$ years for the Sumatra and Indo-Pacific records. Once $\Delta^{14} \mathrm{C}$ levels approach peak levels, however, each record varied in timing, magnitude and attenuation during the post-bomb era and was of limited use in the study for fish with measured $\Delta^{14} \mathrm{C}$ levels in this range. Because it was uncertain what record was most suitable for each species, all $\Delta{ }^{14} \mathrm{C}$ records were considered simultaneously for potential age assignments. In most cases, a combination of records was used to cover a range of possible 


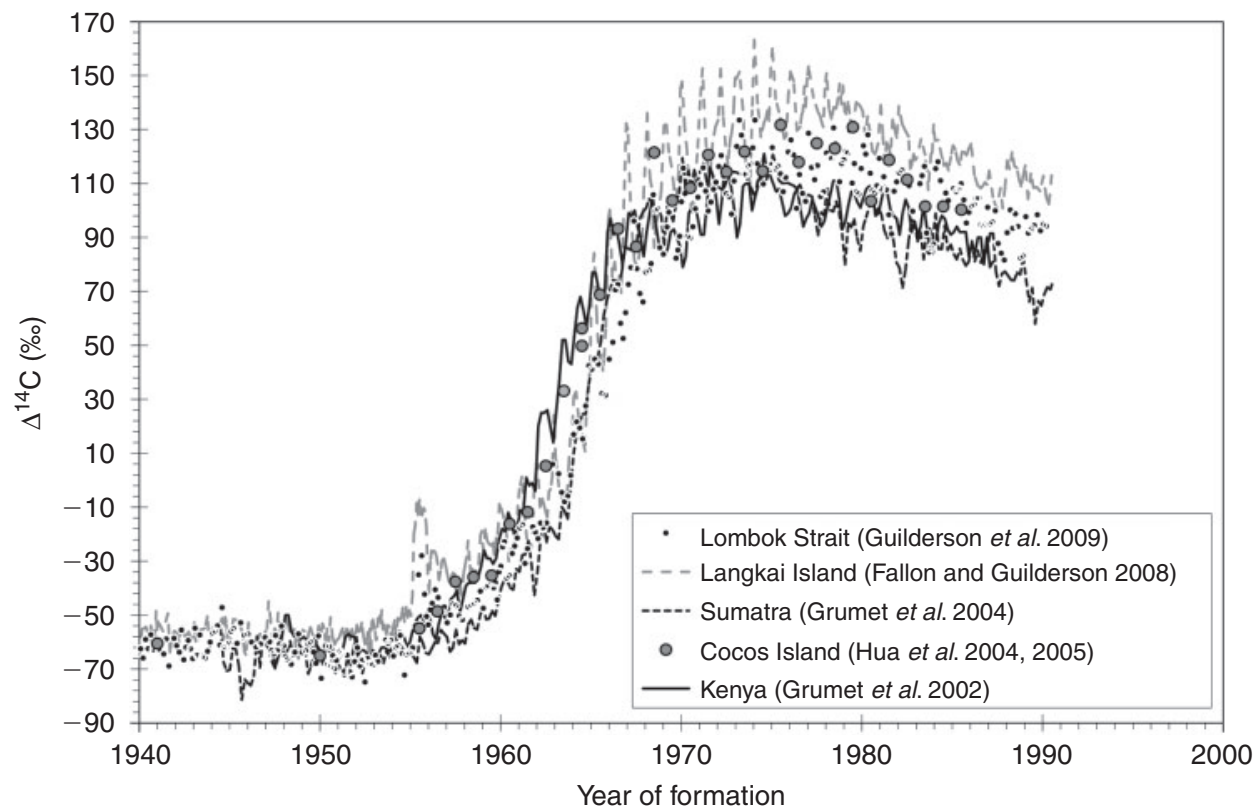

Fig. 1. Plot of $\Delta^{14} \mathrm{C}$ reference records for the Indian Ocean and Indo-Pacific region used to estimate the age of the three reef fish species.

$\Delta^{14} \mathrm{C}$ levels because the actual environmental levels at the locations of fish collections were unknown. Additional information was used to help select among the $\Delta^{14} \mathrm{C}$ reference chronologies.

\section{Bomb radiocarbon dating and age estimation}

For $H$. octofasciatus, the measured $\Delta^{14} \mathrm{C}$ values spanned prebomb to post-bomb peak values ( -68.9 to $145.7 \%$, Fig. $2 a$ ) for fish from 516 to $1240 \mathrm{~mm}$ SL (Table 1). Fish with measured $\Delta^{14} \mathrm{C}$ values in the pre-bomb range were classified as a minimum age based on the year of rise in $\Delta^{14} \mathrm{C}$, resulting in three fish with ages exceeding 40 and 43 years (S270, S2386, S2389). One fish was aged precisely based on the diagnostic portion of the curve where the rise in $\Delta^{14} \mathrm{C}$ provided an age of $34-38$ years (S282). Because of a measured anomaly in the Langkai Island $\Delta^{14} \mathrm{C}$ record, there was a remote possibility of a year of formation near 1955 for this fish, for an age of 43 years. The remaining six fish could not be narrowly classified in age because measured $\Delta^{14} \mathrm{C}$ values approached the broad peak and post-bomb decline $\Delta^{14} \mathrm{C}$ values from the regional references. Specimens provided potential age determinations ranging from 9 to 33 years. Near-peak $\Delta^{14} \mathrm{C}$ values could be more narrowly classified from 16 or 19 years to 28 or 30 years (S2346, S269, $\mathrm{S} 283)$. Some $\Delta{ }^{14} \mathrm{C}$ values fell in a region of the curve that crossed a wide range of possible birth years (1967-89; S291, S296) and one sample crossed two areas of the curve (both rise and decline years) for a potential age of either 28-33 years or $<19$ years (S2365) respectively.

Estimation of age for $H$. octofasciatus using growth-zone counts provided varying degrees of certainty because of the range in potential age classifications based on the $\Delta^{14} \mathrm{C}$ reference curves (Table 1). In general, no age reader provided a completely accurate set of age estimates for the specimen series (Fig. 2b). For fish where $\Delta^{14} \mathrm{C}$ age was not well defined because of a wide range of potential ages, errors in age could only be grossly identified when lying outside the range (e.g. specimen S296 was over aged by at least 5 years by reader ANU-1). For the three fish with birth years in the pre-bomb era, only an underestimation of age could be determined (e.g. specimen S270 was under aged by at least 11 years by reader WA-1). The most diagnostic age determination from sample S282 provided the most discriminating information for the age readers; readers WA-1 and ANU-1 were accurate in age estimations to within a few years, yet reader WA- 2 under aged by 6-10 years (a 4-year range for the rise in $\Delta^{14} \mathrm{C}$, ignoring the remote possibility of the $\Delta^{14} \mathrm{C}$ rise anomaly in 1955). Based on these age data, $H$. octofasciatus can live more than 43 years and accurate age estimation from growth-zone counting is feasible (Table 4).

For $E$. carbunculus, the measured $\Delta^{14} \mathrm{C}$ values spanned the periods of rising $\Delta^{14} \mathrm{C}$ and post-bomb peak values $(-21.2$ to $124.2 \%$, Fig. $3 a$ ) for fish that ranged in length from 268 to $932 \mathrm{~mm}$ SL (Table 2). One fish provided a measured $\Delta{ }^{14} \mathrm{C}$ value that could be aged precisely based on the diagnostic portion of the curve at 35-39 years (S431). Because of a measured anomaly in the Langkai Island $\Delta{ }^{14} \mathrm{C}$ record, there was a remote possibility of a year of formation near 1955 for this fish (S431), for an age of 43 years. The remaining nine fish could not be narrowly classified in age because measured $\Delta^{14} \mathrm{C}$ values approached the broad peak and post-bomb decline $\Delta^{14} \mathrm{C}$ values from the regional references. Specimens provided potential age determinations ranging from 3 to 33 years. Near-peak $\Delta^{14} \mathrm{C}$ values were classified broadly and did not provide a clear determination of age (e.g. sample S485 could have been 3-32 years old). Three other near-peak samples could initially be classified as covering a range from 12 to 31 years based on all reference curves (S477, S444, S449); it is possible, however, that the range could be reduced to 16 to 30 years because peak values were more similar in magnitude to the Cocos (Keeling) 

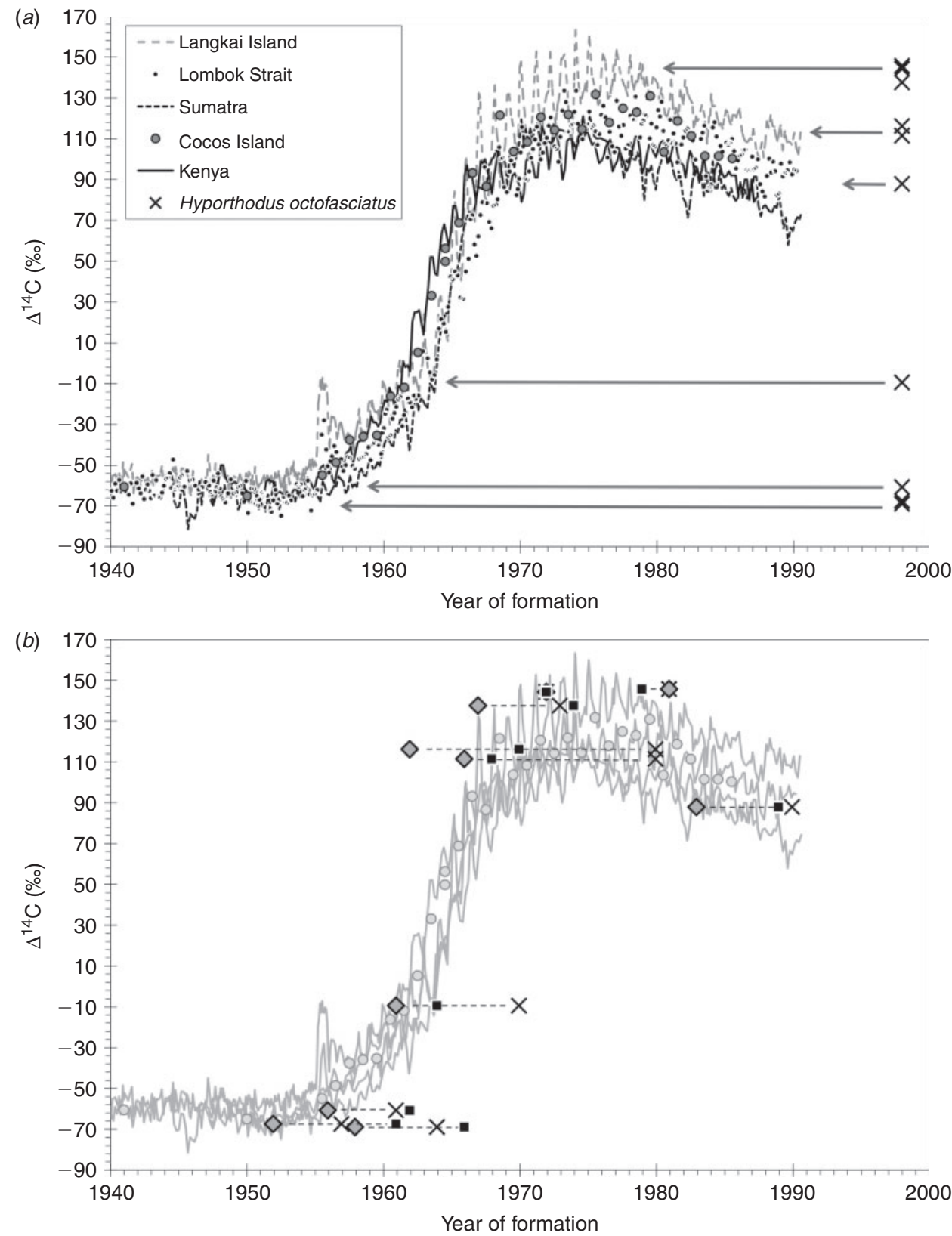

Fig. 2. (a) Age estimation of Hyporthodus octofasciatus by projection back in time to the $\Delta^{14} \mathrm{C}$ reference records. The ' $x$ ' represents the collection year for the fish sample plotted at the measured $\Delta^{14} \mathrm{C}$ level (Table 1). (b) Calculated birth of Hyporthodus octofasciatus (from growth zone-derived age estimates) for three age readers plotted relative to the measured $\Delta^{14} \mathrm{C}$ value from otolith core material (Table 1). Individual fish specimens are connected by dashed lines to illustrate the extent of reader agreement or disagreement (diamond, ANU-1; square, WA-1, cross, WA-2)

Islands $\Delta^{14} \mathrm{C}$ record. The remaining four fish could be more narrowly classified because the measured $\Delta^{14} \mathrm{C}$ values crossed two areas of the curve, both rise and decline years, for a potential age of either near 30 years or $<20$ years (S400, S567, S388, $\mathrm{S} 435)$. In this case, two fish could be further classified based on the assumption that the larger fish were older than young fish with similar $\Delta^{14} \mathrm{C}$ levels; therefore, a minor assumption leads to two additional validated age estimates at 28-32 years (S388) and $30-33$ years $(\mathrm{S} 435)$.
Estimation of age for E. carbunculus based on growth-zone counts also provided varying degrees of certainty because of the range in potential age classifications based on the $\Delta^{14} \mathrm{C}$ reference curves (Table 2). In general, age reader WA-2 provided the greatest level of agreement with the potential ages from $\Delta^{14} \mathrm{C}$ reference curves (Fig. $3 b$ ). For fish where $\Delta^{14} \mathrm{C}$ age was not well defined, errors in age could only be grossly identified when lying outside the range (e.g. specimen S435 was over aged by at least 5 years by reader WA-1). The most diagnostic age 
Table 4. Diagnostic otolith samples that provided the greatest precision in terms of age with samples that also provided a minimum longevity estimate for each species

\begin{tabular}{|c|c|c|c|c|c|c|}
\hline Species & $\begin{array}{l}\text { Sample } \\
\text { number }\end{array}$ & $\begin{array}{l}\text { Fish length } \\
(\mathrm{mm}) \mathrm{SL} / \mathrm{FL}^{\mathrm{A}}\end{array}$ & $\begin{array}{l}\text { Otolith weight } \\
\text { (g) }\end{array}$ & $\Delta^{14} \mathrm{C}(\%)$ & $\Delta^{14} \mathrm{C}$ Birth year & $\begin{array}{c}\Delta^{14} \mathrm{C} \text { Age range } \\
\text { (years) }\end{array}$ \\
\hline \multirow[t]{4}{*}{ Hyporthodus octofasciatus } & $\mathrm{S} 282$ & 983 & 1.3791 & $-9.4 \pm 4.8$ & $1960-64^{\mathrm{B}}$ & $34-38$ \\
\hline & $\mathrm{S} 270$ & 1028 & 1.8202 & $-68.9 \pm 5.4$ & $<1955$ & $>43$ \\
\hline & S2386 & 1220 & 2.3716 & $-60.7 \pm 4.7$ & $<1958$ & $>40$ \\
\hline & S2389 & 1240 & 3.0405 & $-67.4 \pm 4.6$ & $<1955$ & $>43$ \\
\hline \multirow[t]{3}{*}{ Etelis carbunculus } & S388 & 884 & 0.3291 & $84.7 \pm 4.3$ & $1966-70^{\mathrm{B}}$ & $28-32$ \\
\hline & S431 & 886 & 0.4502 & $-21.2 \pm 4.1$ & $1959-63^{\mathrm{C}}$ & $35-39$ \\
\hline & S435 & 932 & 0.3601 & $75.1 \pm 5.0$ & $1965-68^{\mathrm{B}}$ & $30-33$ \\
\hline \multirow[t]{4}{*}{ Lethrinus nebulosus } & N1 & 520 & 0.6558 & $9.4 \pm 8.4$ & $1962-65$ & $27-30$ \\
\hline & N3 & 522 & 0.5857 & $-10.3 \pm 8.2$ & $1960-64^{\mathrm{C}}$ & $27-31$ \\
\hline & $\mathrm{N} 2$ & 553 & 0.6015 & $-19.8 \pm 8.1$ & $1959-63^{C}$ & $28-32$ \\
\hline & N5 & 585 & 0.7004 & $4.8 \pm 8.2$ & $1962-64$ & $26-28$ \\
\hline
\end{tabular}

${ }^{\mathrm{A}}$ Fish length for $H$. octofasciatus and E. carbunculus was SL, and FL for L. nebulosus.

${ }^{\mathrm{B}}$ Younger age scenario was eliminated based of reasonable assumptions of increasing age with increasing fish size.

${ }^{\mathrm{C}}$ The remote possibility of incorporating the minor spike measured for 1955 was ignored because it is unlikely.

determination from specimen S431 provided the most discriminating information for the age readers; both readers WA-1 and ANU-1 underestimated age by 2-6 years, whereas reader WA-2 was in marginal agreement by 1 year (a 4 -year range for the rise in $\Delta^{14} \mathrm{C}$, ignoring the remote possibility of the $\Delta^{14} \mathrm{C}$ rise anomaly in 1955). From these age data, E. carbunculus can live at least 35-39 years and accurate age estimation from growthzone counting is feasible (Table 4).

For L. nebulosus, the measured $\Delta^{14} \mathrm{C}$ values spanned the periods of rising $\Delta^{14} \mathrm{C}$ and post-bomb peak values ( -19.8 to $178.9 \%$, Fig. $4 a$ ) for fish that ranged in length from 297 to $585 \mathrm{~mm}$ SL (Table 3). Four fish provided measured $\Delta^{14} \mathrm{C}$ values that could be aged precisely based on the diagnostic portion of the curve. Two were in a position that provided no complications and age was assigned to within 1-2 years; N1 was 27-30 years old and N5 was 26-28 years old. The other two specimens had a remote chance of complications from the measured anomaly in the Langkai Island $\Delta^{14} \mathrm{C}$ record in 1955 . However, these fish were aged accurately to $\sim 30$ years, with a remote possibility of 36-37 years. Ages for the remaining six fish could not be narrowly classified because $\Delta^{14} \mathrm{C}$ values approached and exceeded peak $\Delta^{14} \mathrm{C}$ values from the region; specimens provided potential age determinations ranging from 0 to 24 years. Measured values of $\Delta^{14} \mathrm{C}$ exceeding all regional $\Delta{ }^{14} \mathrm{C}$ records led us to consider an additional fragmentary record from a Mauritius coral $(1972.5-1977.5, n=3)$ that provided a $\Delta^{14} \mathrm{C}$ reference exceeding $200 \%$ (Toggweiler and Dixon 1991). Because the peak values and reference curve shape are unknown, only a rough estimate from an approximation of the curve could be made; two specimens were possibly aged 14-21 years (N9, N10). Only a broad classification was possible for the remaining four specimens at 3-24 years and 9-23 years, with the exception of N16. Because N16 was an immature fish, age was less questionable and the initial classification of 0-24 years can be narrowed to $\sim 2$ years.

Age estimated for L. nebulosus was made by one reader only (Table 3). Because of the high degree of uncertainty in establishing birth years for $\Delta^{14} \mathrm{C}$ values near and exceeding regional peak references, only 4 of the 10 samples were relatively diagnostic.
It is likely, however, that N14 was under aged by at least 4 years and N4 was over aged by at least 3 years (Fig. $4 b$ ). In general, age reader WA-1 under aged the four diagnostic samples by a few years (N1, N2, N3, N5). At most, these samples were under aged by $3-5$ years, ignoring the remote possibility of the $\Delta^{14} \mathrm{C}$ rise anomaly in 1955. Based on these age data, L. nebulosus can live at least 28 years and accurate age estimation from growth-zone counting is feasible (Table 4).

\section{Bomb radiocarbon dating and diagnostic age estimates}

Bomb radiocarbon dating provided age estimates that were either a minimum age or an age range (Table 4). Minimum age was based on pre-bomb $\Delta{ }^{14} \mathrm{C}$ levels and the last year the levels were recorded in the marine environment. Age estimates that were associated with the rise in $\Delta^{14} \mathrm{C}$ were considered diagnostic because of the narrow range of age possibilities. For H. octofasciatus, a fish measuring $983 \mathrm{~mm}$ SL was 34-38 years old (S282). Three additional fish specimens $>1 \mathrm{~m}$ long and with more massive whole otoliths were more than 40-43 years old. Hence, longevity of $H$. octofasciatus may greatly exceed 43 years. For E. carbunculus, only one sample was clearly associated with the rise in $\Delta{ }^{14} \mathrm{C}$ and could be narrowly aged with no assumptions (S431). Hence, longevity of E. carbunculus exceeds 35 years. Because the $886 \mathrm{~mm}$ SL fish was 35-39 years old, it was reasonable to narrowly age specimens S388 and S435 to $\sim 30$ years based on fish length. For L. nebulosus, four fish with lengths ranging from 520 to $585 \mathrm{~mm}$ SL were 27 to 32 years old.

\section{Discussion}

\section{Bomb radiocarbon dating and age estimation}

Bomb radiocarbon dating has provided validated estimates of age-at-length and longevity for $H$. octofasciatus, E. carbunculus and $L$. nebulosus that were not previously known. The results of the present study also provided evidence that accurate age estimates can be determined using otolith thin sections of these species and that some previous studies have made erroneous assumptions of age, growth and longevity. 

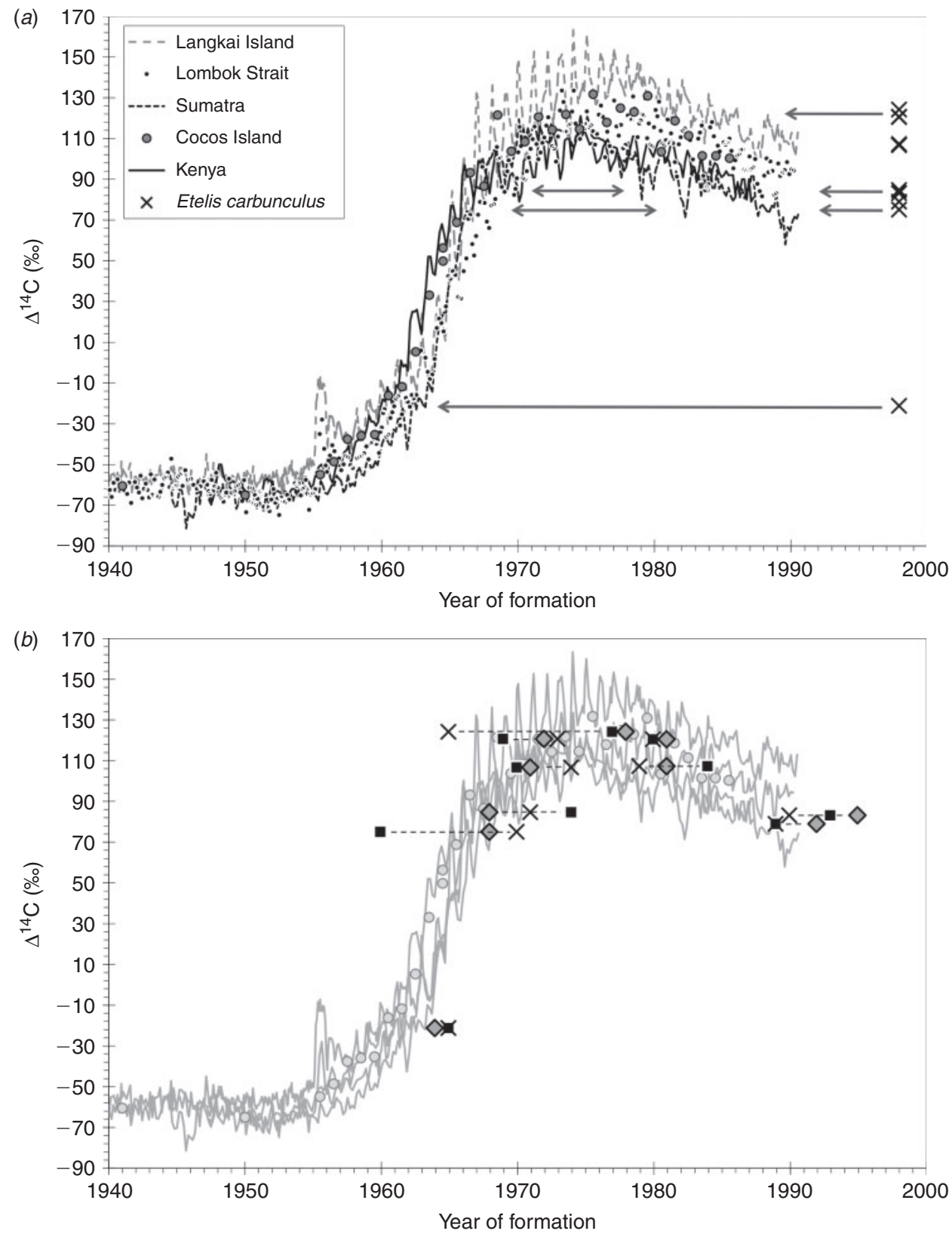

Fig. 3. (a) Age estimation of Etelis carbunculus by projection back in time to the $\Delta^{14} \mathrm{C}$ reference records. The ' $\mathrm{X}$ ' represents the collection year for the fish sample plotted at the measured $\Delta^{14} \mathrm{C}$ level (Table 2). (b) Calculated birth of Etelis carbunculus (from growth zone-derived age estimates) for three age readers plotted relative to the measured $\Delta^{14} \mathrm{C}$ value from otolith core material (Table 2). Individual fish specimens are connected by dashed lines to illustrate the extent of reader agreement or disagreement (diamond, ANU-1; square, WA-1; cross, WA-2).

Bomb radiocarbon dating of $H$. octofasciatus provided the first age estimates of any kind for this species. One fish with a length of $983 \mathrm{~mm}$ SL was $36 \pm 2$ years old and two age readers provided age estimates that were in agreement with the bomb radiocarbon age. For the three oldest fish, age could not be measured precisely by bomb radiocarbon dating. These fish exceeded $40-43$ years of age based on the last measured $\Delta^{14} \mathrm{C}$ levels in coral that could be attributed to the pre-bomb period. Each fish could have been older. With regard to age reading, most of the estimates were less than the minimum age required for bomb radiocarbon dating, which indicates that annual growth zones were being missed for the largest and oldest fish. Hence, these bomb radiocarbon data can be used to refine age assignment protocols to account for the discrepancies in a limited manner. Nevertheless, the longevity of $H$. octofasciatus exceeds 43 years and may be much greater if relative fish lengths and otolith weights are considered. The largest fish (S2389) was $257 \mathrm{~mm}$ longer with otoliths that weighed 2.2 times greater than the fish with a precise age estimate of $36 \pm 2$ years (S282), indicating that this large fish was much older. 

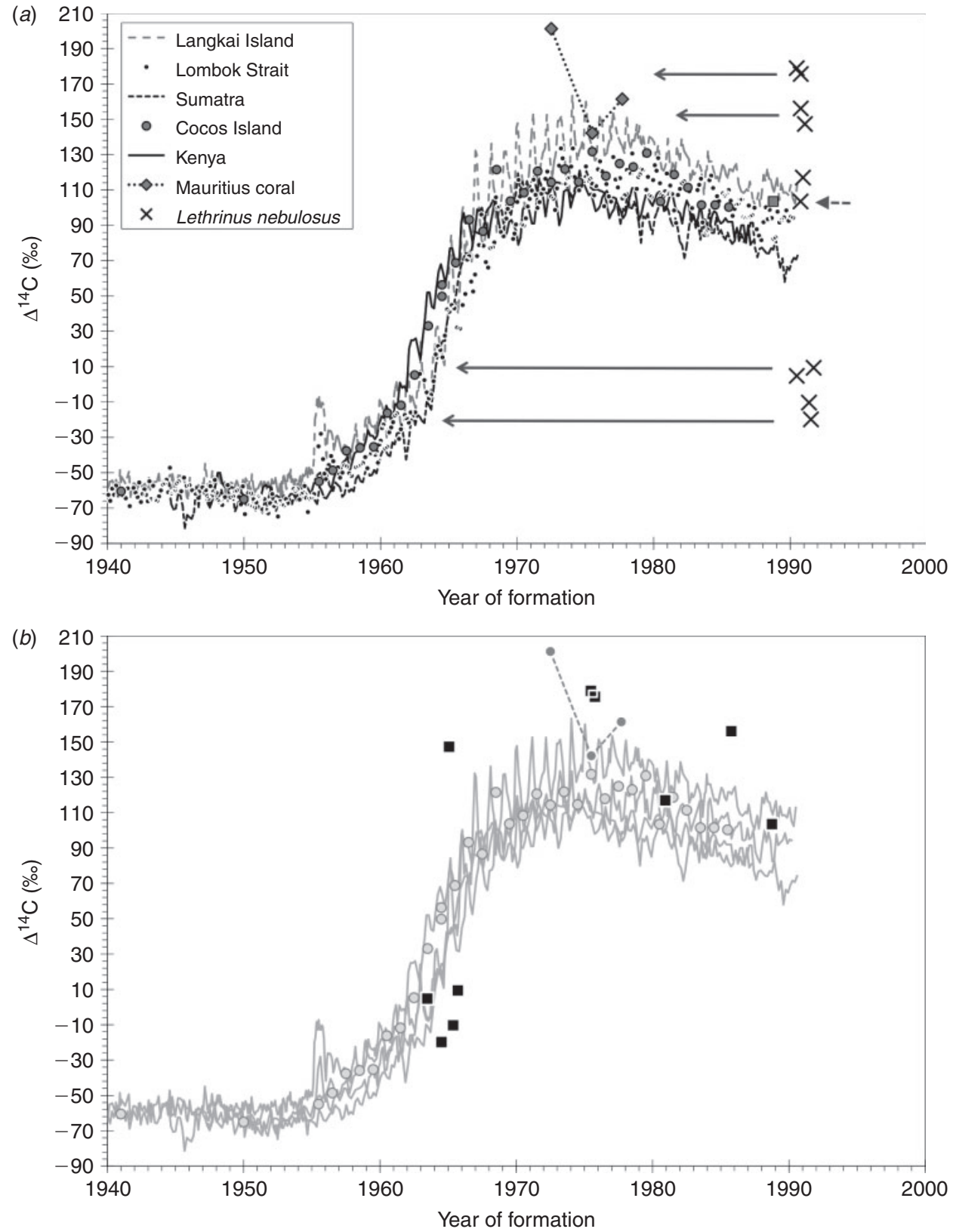

Fig. 4. (a) Age estimation of Lethrinus nebulosus by projection back in time to the $\Delta^{14} \mathrm{C}$ reference records. The ' $\times$ ' represents the collection year for the fish sample plotted at the measured $\Delta^{14} \mathrm{C}$ level. (Table 3). The juvenile sample is plotted as a square at 2 years of age as a possible reference $\Delta^{14} \mathrm{C}$ value for Western Australia. (b) Calculated birth of Lethrinus nebulosus (from growth zone-derived age estimates) for one age reader (square, WA-1) plotted relative to the measured $\Delta^{14} \mathrm{C}$ value from otolith core material (Table 3 ).

Given that $H$. octofasciatus can attain much greater ages, a future validation study could take two possible approaches. One approach is to use fish of similar size that were collected more recently (e.g. collected in 2011 v. 1997). This would increase the potential validated age by up to 14 years, based on the difference in collection year from the informative period in bomb radiocarbon dating $\left(\Delta^{14} \mathrm{C}\right.$ rise $)$. The other possible approach is to use the relatively unique application of lead-radium dating. This approach would require a collection of similar-sized fish and an analysis of the collective lead-radium activity ratio in otolith core material for a sample group (e.g. Andrews et al. 2009). In addition, similarity of otolith weight could be used as a discriminating factor in choosing specimens for the length-based groups.

Bomb radiocarbon dating of E. carbunculus indicated the species is longer lived than previously estimated. The greatest previous estimate of age for E. carbunculus was 28 years for a fish $760 \mathrm{~mm}$ SL (Fry et al. 2006). In the present study, an age of $37 \pm 2$ years was determined for a fish that was $886 \mathrm{~mm}$ SL. This is relatively consistent with Fry et al. (2006) based on a general 
assumption of increasing age with increasing length; although the calculated $\mathrm{L}_{\infty}(791 \pm 43 \mathrm{~mm} \mathrm{SL})$ from their analysis was much less than maximum size and did not encompass the length of this specimen. In contrast, an age of 9 years for a fish $920 \mathrm{~mm}$ SL may be an underestimate by $\sim 20$ years (Smith and Kostlan 1991), given the fish from Vanuatu were E. carbunculus, as discussed previously. Each age estimation study of E. carbunculus has been limited by a lack of accurate age determination for the largest fish. Our findings of greater age also highlight the limitations of the daily increment integration method, which should be restricted to studies of early fish growth.

Regarding age estimates for E. carbunculus from growthzone counting in the present study, age for the oldest fish was underestimated by a few years at most. In some cases, overestimates of age can be used to refine the age estimation protocol (S388 and S435). In addition, a secondary consideration for fish length and otolith weight could exclude the younger age scenario for two fish. Because two of the largest fish had measured $\Delta^{14} \mathrm{C}$ levels similar to the smallest fish, it is reasonable to assume that these fish had birth years on the upper $\Delta^{14} \mathrm{C}$ rise. Hence, two additional validated age estimates can be considered diagnostic (28-32 years and 30-33 years respectively).

Bomb radiocarbon dating of $L$. nebulosus provided a series of four relatively precise age estimates. These validated estimates were in agreement or slightly exceeded the maximum ages estimated for this species in other otolith studies. Ages for L. nebulosus, supported from marginal increment analyses of early growth, have been estimated based on growth-zone counts to 26, 27 and 31 years by Ebisawa and Ozawa (2009), Loubens (1980) and Marriott et al. (2011) respectively. A recent study that estimated a maximum age of 14 years did not age the largest fish in the study (Grandcourt et al. 2006). Compared with our findings, the calculated length-at-age from Loubens (1980) and Ebisawa and Ozawa (2009) would have been lower by at least 16 years for the $520 \mathrm{~mm}$ FL fish. The largest fish that measured $585 \mathrm{~mm}$ FL approached or exceeded asymptotic length for both of the latter studies and their length-at-age prediction was suspect with reference to Western Australian fish. Taken together, these data indicate that the age and growth characteristics of this species differ among regions (Western Australia cf. Okinawa and New Caledonia) and the growth of fish exceeding $\sim 500 \mathrm{~mm}$ FL varies greatly. Otolith weight for fish of similar lengths differed by as much as $50 \%$ for fish near $520 \mathrm{~mm}$ FL.

With regard to the ages estimated for $L$. nebulosus from growth-zone counting in the present study, the largest fish were nearly all in agreement with the bomb radiocarbon dating. Three fish were underaged by 1-2 years. Given that growth zone-derived estimates from this study were relatively accurate, the correlation between age and otolith weight was linear $(y=50.2 x-6.3$, $\left.R^{2}=0.93, n=10\right)$. Especially noteworthy was a fish near $500 \mathrm{~mm}$ FL that had an unusually large otolith and was aged at more than 20 years (N4). Ages of the remaining fish could not be clearly determined because $\Delta^{14} \mathrm{C}$ levels exceeded the regional reference curves. The inability to correlate measured $\Delta^{14} \mathrm{C}$ levels with any portion of the reference $\Delta^{14} \mathrm{C}$ records is an indication that other references are needed for the region of collection.

With the exception of two fish, L. nebulosus specimens were collected from the Houtman Abrolhos Islands off of the southern coast of Western Australia. The most elevated $\Delta^{14} \mathrm{C}$ values were from the otoliths of fish collected from these islands and oceanographic records of $\Delta^{14} \mathrm{C}$ can provide some insight as to why these levels would be so great. Ocean circulation patterns of bomb radiocarbon provide evidence that the southern Indian Ocean gyre was a location of elevated $\Delta^{14} \mathrm{C}$ levels (Key et al. 2004). Measured and modelled radiocarbon levels off of the southern coast of Western Australia indicate that the region experienced a high water-column inventory during 1950-72 (Bard et al. 1989). In addition, Geochemical Ocean Section Study (GEOSECS) stations on the eastern margin of the gyre revealed greatly elevated $\Delta{ }^{14} \mathrm{C}$ levels in 1978 (i.e. 138 to $147 \%$ from $223 \mathrm{~m}$ to the surface at Station 436; Stuiver and Ostlund 1983). Based on ocean circulation observations and modelling, it is possible that the coral collected in Mauritius can function as a proxy for $\Delta^{14} \mathrm{C}$ levels experienced by islands near the margin of the southern Indian Ocean gyre. The sample period was only 5 years (1972-77) with three data points, but the magnitude of the $\Delta^{14} \mathrm{C}$ sample from 1972 is nearly unmatched at $201.2 \%$ (Toggweiler and Dixon 1991). Given that the two L. nebulosus collected at Houtman Abrolhos had $\Delta^{14} \mathrm{C}$ levels approaching $180 \%$, it is reasonable to assume that this island group was exposed to similar levels and that the age estimates were relatively accurate.

\section{Regional $\Delta^{14} \mathrm{C}$ reference chronology}

The compilation of $\Delta^{14} \mathrm{C}$ chronologies from the Indo-Pacific was successful as a tool in providing valid age estimates for all three species in this study. Despite some minor differences in the timing and amplitude of the coral $\Delta^{14} \mathrm{C}$ chronologies, the complications were inconsequential in terms of answering questions about age and longevity. Thus, the measurement of radiocarbon in otolith cores from other fishes of the Indian Ocean and central Indo-Pacific can provide important life history information when compared with these records. The lack of a regional $\Delta^{14} \mathrm{C}$ chronology for the south coast of Western Australia is in need of research. A coral core dating back to the 1950s from the Houtman Abrolhos Islands would provide a $\Delta^{14} \mathrm{C}$ reference chronology that may lead to more specific age determinations for fish from this unique location.

\section{Acknowledgements}

Quan Hua of the Australian Nuclear Science and Technology Organisation, Australia provided $\Delta^{14} \mathrm{C}$ data from Cocos Island and assisted with data acquisition and interpretation. Nancy Grumet Prouty of the US Geological Survey provided assistance with interpreting Indian Ocean $\Delta^{14} \mathrm{C}$ circulation patterns. Stewart Fallon of the Australian National University provided $\Delta^{14} \mathrm{C}$ data from the Langkai Island coral. Thomas Guilderson of Lawrence Livermore National Laboratory provided $\Delta^{14} \mathrm{C}$ data from the Lombok Strait coral. Thanks to Claudia Freiss of Grice Marine Laboratory, Edward DeMartini, Robert Humphreys, Ryan Nichols of NOAA Fisheries and an anonymous reviewer for constructive comments on the manuscript. Funding from the Fisheries Research and Development Corporation (FRDC Project No. 1993/109) supported this research. Logistical support was provided by the Division of Evolution, Ecology and Genetics (Australian National University) and the Department of Fisheries (Government of Western Australia).

\section{References}

Andrews, A. H., Kerr, L. A., Cailliet, G. M., Brown, T. A., Lundstrom, C. C., et al. (2007). Age validation of canary rockfish (Sebastes pinniger) using two independent otolith techniques: lead-radium and bomb radiocarbon dating. Marine and Freshwater Research 58, 531-541. doi:10.1071/ MF07074 
Andrews, A. H., Tracey, D. M., and Dunn, M. R. (2009). Lead-radium dating of orange roughy (Hoplostethus altanticus): validation of a centenarian life span. Canadian Journal of Fisheries and Aquatic Sciences 66, 1130-1140. doi:10.1139/F09-135

Bard, E., Arnold, M., Toggweiler, J. R., Maurice, P., and Duplessy, J.-C. (1989). Bomb ${ }^{14} \mathrm{C}$ in the Indian Ocean measured by accelerator mass spectrometry: oceanographic implications. Radiocarbon 31, 510-522.

Beamish, R. J., McFarlane, G. A., and Benson, A. (2006). Longevity overfishing. Progress in Oceanography 68, 289-302. doi:10.1016/ J.POCEAN.2006.02.005

Broecker, W. S., and Peng, T.-H. (1982). 'Tracers in the Sea.' (LamontDoherty Geological Observatory: Palisades, NY.)

Cailliet, G. M., and Andrews, A. H. (2008). Age-validated longevity of fishes: its importance for sustainable fisheries. In 'Fisheries for Global Welfare and Environment'. (Eds K. Tsukamoto, T. Kawamura, T. Takeuchi, T. D. Beard, Jr. and M. J. Kaiser) pp. 103-120. (TERRAPUB: Tokyo.)

Campana, S. E. (1997). Use of radiocarbon from nuclear fallout as a dated marker in the otoliths of haddock Melanogrammus aeglefinus. Marine Ecology Progress Series 150, 49-56. doi:10.3354/MEPS150049

Druffel, E. R. M., and Linick, T. W. (1978). Radiocarbon in annual coral rings of Florida. Geophysical Research Letters 5,913-916. doi:10.1029/ GL005I011P00913

Ebisawa, A., and Ozawa, T. (2009). Life-history traits of eight Lethrinus species from two local populations in waters off the Ryukyu Islands. Fisheries Science 75, 553-566. doi:10.1007/S12562-009-0061-9

Ewing, G. P., Lyle, J. M., Murphy, R. J., Kalish, J. M., and Ziegler, P. E. (2007). Validation of age and growth in a long-lived temperate reef fish using otolith structure, oxytetracycline and bomb radiocarbon methods. Marine and Freshwater Research 58, 944-955. doi:10.1071/MF07032

Fallon, S. J., and Guilderson, T. P. (2008). Surface water processes in the Indonesian throughflow as documented by high-resolution coral $\Delta^{14} \mathrm{C}$ record. Journal of Geophysical Research 113, C09001. doi:10.1029/ 2008JC004722

Fry, G. C., Brewer, D. T., and Venables, W. N. (2006). Vulnerability of deepwater demersal fishes to commercial fishing: evidence from a study around a tropical volcanic seamount in Papua New Guinea. Fisheries Research 81, 126-141. doi:10.1016/J.FISHRES.2006.08.002

Grandcourt, E. M., Al Abdessalaam, T. Z., Al Shamsi, A. T., and Francis, F. (2006). Biology and assessment of the painted sweetlips (Diagramma pictum (Thunberg 1792)) and the spangled emperor (Lethrinus nebulosus (Forsskål 1775)) in the southern Arabian Gulf. Fishery Bulletin 104, 75-88.

Grumet, N. S., Guilderson, T. P., and Dunbar, R. B. (2002). Meridional transport in the Indian Ocean traced by coral radiocarbon. Journal of Marine Research 60, 725-742. doi:10.1357/002224002762688713

Grumet, N. S., Abram, N. J., Beck, J. W., Dunbar, R. B., Gagan, M. K., et al. (2004). Coral radiocarbon records of Indian Ocean water mass and windinduced upwelling along the coast of Sumatra, Indonesia. Journal of Geophysical Research 109, C05003. doi:10.1029/2003JC002087

Guilderson, T. P., Fallon, S., Moore, M. D., Schrag, D. P., and Charles, C. D. (2009). Seasonally resolved surface water $\Delta{ }^{14} \mathrm{C}$ variability in the Lombok Strait: a coralline perspective. Journal of Geophysical Research 114, C07029. doi:10.1029/2008JC004876

Hua, Q., Woodroffe, C. D., Barbetti, M., Smithers, S. G., Zoppi, U., et al. (2004). Marine reservoir correction for the Cocos (Keeling) Islands, Indian Ocean. Radiocarbon 46, 603-610.

Hua, Q., Woodroffe, C. D., Smithers, S. G., Barbetti, M., and Fink, D. (2005). Radiocarbon in corals from the Cocos (Keeling) Islands and implications for Indian Ocean circulation. Geophysical Research Letters 32, L21602. doi:10.1029/2005GL023882

Kalish, J. M. (1993). Pre- and post-bomb radiocarbon in fish otoliths. Earth and Planetary Science Letters 114, 549-554. doi:10.1016/0012821X(93)90082-K
Kalish, J. M. (2001). Use of the bomb radiocarbon chronometer to validate fish age. Final Report FRDC Project 93/109. Fisheries Research and Development Corporation, Canberra.

Kalish, J. M., Johnston, J. M., Gunn, J. F., and Clear, N. (1996). Use of the bomb radiocarbon chronometer to determine the age of southern bluefin tuna (Thunnus maccoyii). Marine Ecology Progress Series 143, 1-8. doi:10.3354/MEPS143001

Kalish, J. M., Nydal, R., Nedreaas, K. H., Burr, G. S., and Eine, G. L. (2001). A time history of pre- and post-bomb radiocarbon in the Barents Sea derived from Arcto-Norwegian cod otoliths. Radiocarbon 43, 843-855.

Key, R. M., Kozyr, A., Sabine, C. L., Lee, K., Wanninkhof, R., Bullister, J. L., Feely, R. A., Millero, F. J., Mordy, C., and Peng, T.-H. (2004) A global ocean carbon climatology: results from Global Data Analysis Project (GLODAP). Global Biogeochemical Cycles 18, GB4031. doi:10.1029/2004GB002247

Loubens, G. (1980). Biologie de quelques espèces de poissons du lagon NéoCalédonien. III. Croissance. Cah. Indo-Pacific 2, 101-153.

Marriott, R. J., Adams, D. J., Jarvis, N. D. C., Moran, M. J., Newman, S. J., et al. (2011). Age-based demographic assessment of fished stocks of spangled emperor, Lethrinus nebulosus in the Gascoyne Bioregion of Western Australia. Fisheries Management and Ecology 18, 89-103. doi:10.1111/J.1365-2400.2010.00754.X

Neilson, J. D., and Campana, S. E. (2008). A validated description of age and growth of western Atlantic bluefin tuna (Thunnus thynnus). Canadian Journal of Fisheries and Aquatic Sciences 65, 1523-1527. doi:10.1139/ F08-127

Newman, S. J., Williams, D. McB., and Russ, G. R. (1996). Age validation, growth and mortality rates of the tropical snappers (Pisces: Lutjanidae) Lutjanus adetii (Castelnau 1873) and L. quinquelineatus (Bloch 1790) from the central Great Barrier Reef, Australia. Marine and Freshwater Research 47, 575-584. doi:10.1071/MF9960575

Newman, S. J., Cappo, M., and Williams, D. McB. (2000). Age, growth, mortality rates and corresponding yield estimates using otoliths of the tropical red snappers, Lutjanus erythropterus, L. malabaricus and L. sebae from the central Great Barrier Reef. Fisheries Research 48 , 1-14. doi:10.1016/S0165-7836(00)00115-6

Pears, R. J., Choat, J. H., Mapstone, B. D., and Begg, G. A. (2006) Demography of a large grouper, Epinephelus fuscoguttatus, from Australia's Great Barrier Reef: implications for fishery management. Marine Ecology Progress Series 307, 259-272. doi:10.3354/ MEPS307259

Ralston, S., and Miyamoto, G. T. (1983). Analysing the width of daily otolith increments to age the Hawaiian snapper, Pristipomoides filamentosus. Fishery Bulletin 81, 523-535.

Smith, M. K. (1992). Regional differences in otolith morphology of the deep slope red snapper Etelis carbunculus. Canadian Journal of Fisheries and Aquatic Sciences 49, 795-804. doi:10.1139/F92-090

Smith, M. K., and Kostlan, E. (1991). Estimates of age and growth of ehu Etelis carbunculus in four regions of the Pacific from density of daily increments in otoliths. Fishery Bulletin 89, 461-472.

Stuiver, M., and Ostlund, H. G. (1983). Geosecs Indian Ocean and Mediterranean radiocarbon. Radiocarbon 25, 1-29.

Stuiver, M., and Polach, H. A. (1977). Discussion: reporting of ${ }^{14} \mathrm{C}$ data Radiocarbon 19, 355-363.

Toggweiler, J. R., and Dixon, K. (1991). The Peru upwelling and the ventilation of the South Pacific thermocline. Journal of Geophysical Research 96, 20 467-20 497. doi:10.1029/91JC02063

Uchida, R. N., Tagami, D. T., and Uchiyama, J. H. (1982). Results of bottom fish research in the north-western Hawaiian Islands. Southwest Fisheries Science Center Administrative Report H-82-10, Honolulu, Hawaii. 